УДК 78.05

DOI https://doi.org/10.31723/2524-0447-2021-32-1-2

Ірина Олександрівна Шатова

ORCID: 0000-0003-4646-4575

кандидат мистецтвознавства, доцент кафедри хорового диригування

Одеської національної музичної академії імені А. В. Нежданової ir.al.shatova@gmail.com

\title{
ВІРТУАЛЬНИЙ ХОР ЕРІКА ВІТАКЕРА: ІННОВАЦИЙНІ ТЕНДЕНЦІЇ РОЗВИТКУ СУЧАСНОЇ МУЗИКИ
}

Метою статmі є визначення значення хорових інновацій Еріка Вітакера в контексті актуальних стильових тенденції розвитку сучасної хорової музики. Пояснюється стильова унікальність творчого проекту композитора у сфері організації хорового колективу у віртуальному інтернет-просторі i, відповідно, визначення основних принципів формування виконавської стилістики. Наукова новизна роботи полягає у спробі музикознавчої оцінки нових функціональних можливостей віртуалізованого простору мови хорової музики, запропонованого Еріком Вітакером, яке виявилося включеним у сучасний хоровий репертуар. Висновки. Культурно-історичне і ситуативно-прикладне значення хорових інновацій Еріка Вітакера розкривається в контексті провідних стильових тенденцій розвитку сучасної хорової музики. Нині спостерігається особлива актуальність у вивченні унікальної виконавської стилістики хорових творів Вітакера, які активно включилися в культурну реальність сучасного музичного мистецтва. Американський композитор i диригент вразив глобалізовану культурну свідомість безпрецедентною ідеєю музично-комунікативної творчої співпраці, безмежно і нескінченно розширюючи обсяг виконавців $i$, відповідно, звучання хору. Створюється новий змістовний простір хорової музики, який дослівно реалізує ідею «обійміться мільйони» засобами Facebook, Twitter ma Yои Tube віртуальний хор. Так, відтворюється віртуальне й реальне охоплення хоровим звучанням усього людства. Нові хронотопи хорової музики XXI століття, які зумовили висунення на перший план звукової технології сонористики та алеаторики, забезпечують провідні семантичні позиції звукової барвистості хорового тембру і принципово іншої організації фактури з ї̈ гармонійними складниками. Сучасний рівень розвитку хорового мистецтва висуває підвищені вимоги до вивчення хорової звучності, їі основних елементів. Інноваційна хорова реальність організовує нові функціональні можливості віртуалізованого хорового простору, нові програмні образні властивості хорової музики.

(C) Шатова I. O., 2021 
Ключові слова: сучасна хорова музика, віртуальний хор, пандіатонічний стиль, пандинаміка, нові хронотопи.

Shatova Iryna Oleksandrivna, Ph.D. in History of Arts, Associate Professor at the Department of Choral Conducting of Odesa National A. V. Nezhdanova Academy of Music

Eric Whitaker's virtual choir: innovative trends of development of modern music

The purpose of the article is to determine the significance of Eric Whitaker's choral innovations in the context of actual style trends in the development of modern choral music. The style uniqueness of the composer's creative project to organize a choir collective in virtual Internet reality is explained, respectively, and the definition of the basic principles for the formation of performance stylistic. The scientific novelty of the work is an attempt at a musicological evaluation of the new functionalities of the virtualized choral Internet reality of language in choral music, invented by Eric Whitaker, which turned out to be included in the modern choral repertoire. The research methodology is based on the analytical, musicological, chorological, functional approaches, that create a that create a single basis for the study of genre and performance stylistic of Eric Whitaker's choral work. Conclusions. The cultural-historical and situational-applied significance of Eric Whitaker's choral innovations opens in the context of current stylistic trends in the development of modern choral music. Currently, particular relevance is being revealed in the study of the peculiarities of the performance stylistic of Whitaker's choral works, which are actively involved in the cultural reality of modern musical art. The American composer and conductor struck a globalized cultural consciousness with the unprecedented idea of musical and communicative co-creation, expanding the volume of performers, and the sound of the choir, infinitely and endlessly. A new substantial space of choral music is being created, literally realizing the idea of "Embrace Millions" using Facebook, Twitter and You Tube - the virtual choir. This reproduces the virtual, simultaneously real, coverage of the choral sound of all mankind. The new chronotopes of $X X I$ century choral music, which led to the forefront of sound technology, sonoristics and alleatorics, thus provide leading semantic positions in the sound colorfullness of the choral timbre, along with this a fundamentally different organization of texture with its harmonic components. The current level of development of choral art makes high demands on the study of choral sonority, its basic elements. Innovative choral reality organizes new functionalities of a virtualized choral reality.

Key words: modern choral music, virtual choir, pandiatonic style, pandynamics, the new chronotopes.

Актуальність теми дослідження зумовлена тим, що хорове мистецтво постійно веде пошук нових форм існування, які реалізуються через трансформацію традиційних канонів і принципів хорового виконавства. Нині це викликало нові звукові 
норми та уявлення, нові звукосполучення, оновлену музичну мову. Хорова творчість Еріка Вітакера, якому присвячена наша стаття, підтверджує саме такий шлях розвитку нової хорової виконавської естетики.

Сучасна хорова музика стилістично різноманітна. Зміст хорової музики XX-XXI століть, хорові твори, написані в композиторських техніках XX століття, як-от додекафонія, сонористика, алеаторика, мікрополіфонія, нова тональність, модальність, формульна композиція, відрізняються від музичного мистецтва минулого. Найголовнішим є те, що виконання цієї музики викликає певні труднощі, пов'язані з хорознавською методикою і співочою технологією, як-от уміння працювати 3 новими засобами вокально-хорової виразності, 3 новими виконавськими прийомами, із сучасними формами інтонування.

Першоплановими стають специфічні завдання практичного втілення щодо того, як виконувати цю музику. Сучасна хорова виконавська практика постійно вимагає нових методичних розробок, теоретичного осмислення i детального вивчення специфічних особливостей сучасного хорового письма, новаторських способів вокально-хорової виразності. Такий стан справ у сучасній хоровій музиці висуває до виконавської діяльності, педагогічної та науково-методичної роботи нові завдання і вимоги.

Найголовнішим є ускладнення мови сучасного хорового письма, застосування нових засобів у сфері гармонії, ритму, що допомагає хоровим співакам відточувати свою художню i технічну майстерність, розвивати музичний смак, чуйність слуху, освоювати контрапунктичну гнучкість. Це створює основу для творчого і професійного зростання виконавців, для розширення їх музичного та художнього світогляду. Завдання сучасного хорознавства полягає в тому, щоб виробити підходи, шляхи вирішення цих проблем, які відповідають часу. Тому так важливо використовувати в хормейстерській технології розробок, які допомагають опанувати нові способи вокально-хорової виразності (дослідження Є. Білявського [3], Б. Тевлина [8], I. Батюк [2], Є. Бондар [4] та ін.).

Ерік Вітакер перший вигадав і створив найбільший у світі віртуальний хор. Віртуальний хор (онлайн-хор) - це фантастичний проект, коли тисячі людей з усього світу, які не бачать одне одного, співають задану композицію на камеру. Потім 
відсилають записи диригенту, а той «зводить» їхні голоси разом і отримує хорову звучність небаченої краси і сили. Така музично-комунікативна ідея отримала надзвичайно активний відгук. Причиною цього є не ії зовнішня ефектність, а оригінальність і естетична глибина нового змістовного простору хорової музики, створеного Вітакером. Для обговорення хорової творчості Еріка Вітакера у контексті еволюції сучасних тенденцій хорового мистецтва розглянемо специфіку співочої технології виконання саме такої музики.

Метою статті $\epsilon$ розкриття значення хорових інновацій Еріка Вітакера у контексті актуальних стильових тенденції розвитку сучасної хорової музики. Пояснюється стильова унікальність творчого проекту композитора у сфері організації хорового колективу у віртуальному інтернет-просторі і, відповідно, визначення основних принципів формування виконавської стилістики.

Наукова новизна роботи полягає у спробі музикознавчої оцінки нових функціональних можливостей віртуалізованого хорового простору мови хорової музики, запропонованого Еріком Вітакером, яке виявилося активно включеним у сучасний хоровий репертуар.

Виклад основного матеріалу. Ерік Вітакер - один із найпопулярніших і часто виконуваних композиторів. Його глобальний успіх був посилений завдяки його досягненням як диригента, новатора, телеведучого і харизматичного публічного оратора, а також завдяки успіху його записів. Гучну славу музикантові, який у професійних колах отримав визнання ще в 90-х, уже в новому тисячолітті принесли сміливі експерименти щодо керівництва імпровізованим хором користувачів Інтернету. Записані віртуальним хоровим колективом композиції стали новим явищем у музичному мистецтві. Вперше цей музичний проект - віртуальний хор - зібрався у 2009 році, щоб виконати твір «Lux Aurumque». Щоб набрати співаків для свого проекту, Ерік Вітакер звернувся до своїх шанувальників через Facebook, Twitter $i$ YouTube. Співаки співали одну й ту ж пісню, далі ці кліпи були змонтовані в одне велике 3D-відео. Ерік Вітакер зізнається, що залежить від соціальних мереж. Композитор отримує величезне задоволення від перегляду відео, на яких люди з різних куточків планети виконують його творіння (диригують, співають, грають), адже його це надихає, стимулює до подальшої творчості (він багато пише про це 
на своїй сторінці в Facebook). Але головним своїм завданням Ерік Вітакер ставив не просто заспівати окремі партії і звести їх разом, а зробити повноцінний Віртуальний хор. Йому було цікаво домогтися спільної творчості в музиці. Діапазон роботи Еріка Вітакера перетинає звичайні межі, встановлені для різних музичних жанрів. Його незвичайний талант дозволяє об'єднувати людей з усіх країн світу.

Багато творів Еріка Вітакера увійшли в стандартний хоровий та симфонічний репертуар і стали предметом вивчення у багатьох наукових роботах та дисертаційних дослідженнях. Можна назвати такі дисертаційні праці: Andrew Lloyd Larson «Textual and Harmonic Density in Selected Choral Works by Eric Whitacre» (2004), Phillip A. Swan. In His Own Words: The Choral music of Eric Whitacre from 1991-2004» (2016), Angela Hall «Added-Tones Sonorities in the Choral Music of Eric Whitacre» (2012); a також дослідження Marc Shapiro, John Byun, Kenneth Lee Owen, John Hairel, Shane Lunch [13], в яких аналізуються музично-теоретичні позиції творчості композитора.

Стиль музики, в якому пише Ерік Вітакер, важко певною мірою позначити і проаналізувати. Це тип музики, який називають по-різному: неотональним, пантональним, посттональним. I композитори цього напряму, як-от К. Дебюссі, М. Равель, Б. Барток, І. Стравінський, використовували у своїх композиціях природу діатонічного звукоряду, уникаючи використання більш традиційної функціональної гармонії. Водночас твори Еріка Вітакера лежать у руслі американської традиції, нагадуючи часом роботи Семюела Барбера, а іноді й Чарльза Айвза, але його підхід завжди оригінальний. У своїх ефектних хорових опусах композитор не боїться ні незвичайних гармоній, ні стильової еклектики, ні експериментів 3 електронікою.

Часто стиль Еріка Вітакера визначають як пандіатонічний. Пандіатоніка («вседіатоніка») - нашарування діатонічних елементів і послідовностей, що призводить до використання всього хроматичного звукоряду. Пандіатоніка - це стиль гармонійного письма, в якому діатонічні співзвуччя вживаються вільно, часто поза правилами традиційної гармонії; паралельний рух вгору або вниз двох або більше голосів, за якого між цими голосами зберігається одна і та ж інтервальна відстань. Цей термін увів у музичний побут американський музикознавець, лексикограф, композитор, диригент і піаніст Слонім- 
ський Микола Леонідович (англ. Nicolas Slonimsky - Николас Слонимски; 15 (27).04.1894, Санкт-Петербург, Російська імперія - 25.12.1995, Лос-Анджелес. Брат письменника Михайла Слонімського, дядько композитора Сергія Слонімського, двоюрідний брат польського поета Антонія Слонімського). Нововведення Миколи Слонімського в техніці композиції і музичної термінології, як-от пандіатоніка - рівноправне застосування 7 звуків діатонічної гами в мелодійних, контрапунктичних і гармонійних комбінаціях, обгрунтовані в його трактаті «Thesaurus of Scales and Melodic Patterns» («Тезаурус звукорядів і мелодичних фігурацій» (1947)), а також у словнику музичних термінів XX ст., який увійшов до його праці «Музика з 1900Х». Серед музично-теоретичних досягнень Миколи Слонімського є так званий «гросмуттеракорд». До цього австрійський композитор і теоретик Ф.Г. Кляйн вивів «муттеракорд» акорд із 12-ти різних звуків, віддалених одне від одного на 11 різних інтервалів. Деякий час уважалося, що він унікальний. Слонімському вдалося довести неунікальність такого акорду, а також побудувати унікальний варіант подібного акорду, але 3 додатковою умовою: інтервали в ньому розташовані за принципом симетрії інтервальної оборотності (з тритоном (тобто самооборотним інтервалом) у центрі). У 1953 р. Слонімський опублікував свій знаменитий «Лексикон музичних інвектив» («Lexicon of musical invective»), до якого увійшло безліч критичних текстів із газетних і журнальних публікацій, а також із наукових монографій. «Надзавдання» книги - продемонструвати аналогію між неприйняттям публікою новаторською музики XX століття (особливо 12-тонової музики нововіденців та І. Стравінського) і подібним же неприйняттям визнаних нині як шедеврів композиторських творів попередніх століть [9].

Найбільшу популярність Еріку Вітакеру принесли хорові твори. Дивовижне звучання хорової музики Еріка Вітакера знайшло широке визнання у слухачів і критиків. Рецензенти пишуть про «електричні гармонії, які лякають», про «вільні, потойбічні стани, які створені розкішними, сяючими акордами застиглої гармонії з рясними, але м'якими дисонансами». Один критик описує характерну ознаку композиційного стилю Вітакера як «серпанок кластерних акордів, які звучать із глибокими басами і мерехтливими верхніми голосами, створюючи захоплену і застиглу красу часто «нерозв'язаних» акордів» [14]. 
У хоровому та інструментальному жанрах композитор використовує «акорди Вітакера» або пандіатонічні кластери, які зазвичай розташовуються в послідовному збільшенні або зменшенні щільності. Досягається це зростання або спад шляхом поділу голосів (divisi), в деяких випадках - на 18. Загалом, однією з найбільш характерних рис композитора $\epsilon$ саме поділ хорових партій на велику кількість голосів - divisi. Ці співзвуччя часто можна прочитати як септ- або нон-акорди із секундовим або квартовим затриманням. Можливо, його найвідоміший акорд - це тонічний мажорний тризвук із додаванням другого або четвертого натуральних ступенів. Що стосується ритму, то композитор часто використовує складний або змішаний метр, його твори іноді включають часті зміни метра і незвичайні ритмічні малюнки. Інша особливість творів Еріка Вітакера полягає у використанні алеаторичних прийомів, а також незвичайних інструкцій до трактування, включаючи елементи сценічної дії або реквізиту.

В одному з інтерв’ю Ерік Вітакер говорить: «Коли я починаю писати, то відразу починаю імпровізувати: акорд, який чую, - це як зародок, який я відразу починаю змінювати i 3 якого починається мій шлях, перший крок. Коли уточняється основна ідея, то я починаю розробляти загальну звукову палітру, яка потім буде втілена, тому твір уже саме поступово визначається і створюється. Так народжується мій Всесвіт...». I ще: «Для мене немає жодної різниці між моєю особистістю і моєю музикою. Важко пояснити, але коли я чую певні музичні звуки, то це схоже на те, що хтось говорить моє справжнє ім'я. Я часто використовую одні й ті ж акорди або співзвуччя акордів у різних творах, цитуючи себе, і це не тому, що у мене скінчилися ідеї, а тому, що ці акорди і співзвуччя представляють мене» [14]. Таким чином, використовуючи цю звучність як відправну точку, Вітакер іiі розвиває, збагачує і доповнює низкою звуків, які «розфарбовують» музику різнокольоровими фарбами. Про це говорить Шейн Лінч у дисертаційному дослідженні, присвяченому загальним стилістичним напрямам у музиці Еріка Вітакера, Рене Клаузена i Мортена Лаурідса. Лінч стверджує, що ці композитори основоположники нового стилю в американській сучасній музиці - неоімпресіонізму. Одна зі стилістичних якостей неоімпресіонізму - це, звичайно, звучність. Музика неоімпресіонізму бере багато від імпресіонізму, найголовнішим $є$ те, що 
вона акцентує увагу на специфіці спектра живої звучності як самостійної цінності, яка приносить колір у музичну думку, часто залишаючи іiї при цьому незавершеною і невизначеною [12].

Хорова творчість Еріка Вітакера пов'язана з особливими стилістичними знаками, як-от із «мовою» сонористики, 3 роз'ясненням сонористичних прийомів, що спонукає до спеціального їх вивчення. Динамічний розвиток системи музично-виразних засобів у мистецтві XX-XXI століть, супроводжується в деяких стилях висуненням на перший план звукової барвистості. Придбання звуком художньої якості є, можливо, найбільш специфічним акустичним i смислоутворювальним процесом (у сонористиці, алеаториці) і зводить проблематику звукової барвистості тембру в низці найважливіших тем у сучасній системі виразних засобів хорового мистецтва. Сонористика як темброво-колористична категорія найбільш властива музичній мові XX-XXI століть. У музиці XX століття виникла тенденція засобами гармонії і фактури посилювати, підкреслювати темброво-колористичну сторону звучання (паралелізми, кластери, звукові поля тощо). Особливим напрямом у використанні тембру є сонорика як метод комбінації різних звукових і сонористичних ефектів. Дійсно, опанування сонористичних композицій вимагає суттєвої зміни диригентських установок і особливих вокально-ансамблевих навичок хору.

Новітні композиторські твори, які йдуть попереду можливостей хорового виконавського мистецтва, дозволяють хоровому диригенту шукати нові способи вокально-хорової виразності. Особливі труднощі співакам і хормейстерам доставляє оновлена музична мова сучасних хорових партитур: у ній трапляються інтонаційні вияви нової гармонійної системи, нові звукосполучення, дисонувальні співзвуччя, вільна хроматика, безліч особливих властивостей і прийомів артикуляції тощо.

В основі гармонійного звукоутворення в сучасній хоровій партитурі - мелодійна активність голосів, широке використання неакордових звуків, паралельне голосоведіння тощо. Хорові твори (починаючи з другої половини XX століття) часто пишуться з поділом на велику кількість самостійних голосів, що вимагає від кожного співака-ансамбліста високого рівня володіння голосом, гострого слуху, інтелекту. У виконавській роботі над хоровим звуковидобуванням (поряд із 
досягненнями ансамблевого співу, спрямованого на згладжування вокальних тембрів) необхідно виявляти голосові можливості кожного учасника хору (як тембрового забарвлення). Тому сучасні хорові партитури вимагають від хорових співаків вільного поводження з інтонаційним матеріалом, опанування і проспівування складної інтерваліки, глибокого інтелектуального й емоційного проникнення. Абсолютно новим явищем у хоровій музиці XX століття є кластери - позафункціональні гармонійні комплекси, побудовані тільки з тонів і півтонів. Тому особливі труднощі хорового строю, якісно інші проблеми інтонування під час виконання сучасної музики, яка використовує поліладову, політональну і додекафонну техніку, визначають особливу (часто відмінну від традиційної) специфіку вокально-ансамблевої виконавської технології.

Дійсно, труднощі виконання новітньої музики особливо великі саме в хоровому співі, їх помітно більше, ніж у піаністів, оркестрових музикантів (співати так, як раніше не співали, чути так, як раніше не чули). Як справедливо зазначає Б. Тевлін, «головне тут - природне слухання нової музики, засноване на органічному сприйнятті всього свіжого, незнайденого, непридбаного у сфері музичної мови і техніки композиції. Слухання іншої (порівняно з попереднім досвідом) природи кожного окремого звука, кожної паузи, звукової матерії в цілому, іншої, що виросла з попередніх епох, із їх і заперечення, і продовження, і критичного осмислення» [8, с. 184].

Наведемо як приклад найвідомішу хорову композицію Еріка Вітакера «Lux Aurumque», створену у 2000 р. у Лос-Анджелесі, в якій яскраво виявляється його незвичайний стиль (саме цей твір було виконано першим у віртуальному інтернет-проекті у 2009 році). Автором віршів $є$ відомий поет Едвард Еш (Edward Esch), латинський переклад здійснив друг композитора, американський поет Чарльз Ентоні Сільвестрі (Charles Antony Silvestri):

\section{"Lux Aurumque»}

Lux, calida gravisque, pura velut aurum,

Canunt, et canunt angeli, canunt

Molliter natum, modo natum.

Цей твір є одним із небагатьох, який був створений Вітакером для виконання у храмі, особливо на Різдво. Ця музика пройнята неймовірним світлом Різдва. У тексті йдеться про «світло» і «співи ангелів», тому стиль письма Еріка Вітакера 
в цьому творі відповідає прозорому і повітряному характеру тексту. Ерік Вітакер говорив, що цей твір вимагає особливої теплої інтонації з мінімальним вібрато. Найскладнішим завданням, на думку композитора, є знаходження «правильного» сопрано solo, яке повинно м'яко звучати на високих сольних лініях з особливою витонченістю і красою.

Твір написаний для мішаного хору і сопрано solo. Композитор використовує divisi в кожній партії, що гармонійно насичує хоровий виклад, створюючи ефект ослаблення i посилення звучання. Ерік Вітакер, маніпулюючи масою i щільністю звука, значно перетворює звучання, що дозволяє втілювати неординарні художні ідеї. Вміло розподіляючи хорові голоси в різних теситурних умовах, композитор «грає» обертоновим складом звука, чим отримує можливість рельєфно виокремити смислову лінію або затушувати іiі у звучанні цілого. При цьому під час співу характеристика звука багато в чому залежить від перебудови системи резонаторів, тобто зміни форманти.

Під час виконання слід домагатися ефекту «мерехтливого» звучання (the effect of shimmering clarit). Такого ефекту автор досягає завдяки тимчасовому поділу всіх хорових партій: неповний тризвук натурального мінору перетворюється в співзвуччя неймовірної краси і тембральної насиченості. Таке співзвуччя знову повертається у вихідне положення, повторюючись чотири рази майже без змін, лише в третьому проведенні додається партія solo сопрано і посилюється динаміка на один нюанс: із $p$ динаміка поступово збільшується до $m p, m f$ (т. т. 1-8). Композитор створює неймовірний стан мерехтіння, світіння за допомогою досить яскраво вираженої хвилеподібної динаміки в спокійному темпі і максимально плавного зв'язкового штриха. У заключній частині ситуація подібна до початку твору, але композитор опустив все на октаву нижче, зменшив динаміку на нюанс тихіше і виключив альтову партію. 3'являється хвилеподібність у динаміці, як і на початку твору (так побудовані чотири такти твору (т. т. 30-34)). Із 34 такту партія сопрано ділиться на три голоси, другі і треті сопрано продовжують співати попередні звуки, а перші - виходять на звук соль дієз першої октави і на динаміці рpр тримають його до кінця твору, тобто неповні чотирнадцять тактів. Це дуже складний момент для виконання, але за умов досягнення врівноваженого ансамблевого 
звучання створюється неймовірний ефект безперервності, руху, «вознесіння» (т. т. 34-48).

Найголовніше відчуття і загальний ефект від цього твору співіснування і стану руху, і стану нерухомості, тобто статичності. Ерік Вітакер називає такий рух-вібрацію «breathing motive» (мотив, що дихає). Обсяг і «форма» звука яскраво виявляють виразність у сонорній тканині. Коливання по-різному розподіляються в просторі, тому проекція звука представляється в різних обсягах і «формі». Саме звук, його висотний i тембральний статус став більш багатозначним, відбувається процес переродження хорової звукової барвистості, яка виступає в абсолютно новій формі (специфічного музичного засобу) і здатна самостійно виконувати змістовні функції.

Динамічне-часові властивості звука мають суттєве значення для створення художнього твору. Щільно стискаючи або заповнюючи весь акустичний простір, нескінченно триваючи або пульсуючи, звук (подібно до фізичних тіл) знаходить «контури» й існує у вигляді точки, плями (щільного, невеликого за обсягом, поступово виникає і швидко зникає), хвилі (руху, створеного плавним переходом із точки в широку звук-зону і поверненням до початкового стану), лінії (руху звук-зони лінійною траєкторією). Різноманіття «форм» звука, що показує його здатність стискатися в точку і розростатися до нескінченності, виявляє великий образно-художній потенціал, що відкриває нові грані виразності звука [12].

Таким чином, Ерік Вітакер створює нові уявлення про динаміку музичного хорового звучання - «пандинаміку», яка включає і мікродинаміку. Так, створюється новий змістовний простір хорової музики і відтворюється віртуальне і реальне охоплення хоровим звучанням усього людства, тобто глобалізований хоровий хронотоп.

Висновки. Культурно-історичне і ситуативно-прикладне значення хорових інновацій Еріка Вітакера розкривається в контексті актуальних стильових тенденцій розвитку сучасної хорової музики. Стильова унікальність хорових інновацій Вітакера визначається в пошуках нової виразності, яка маніпулює масою і щільністю звука, значно перетворюючи звучання, відкриває нові темброві можливості хору, знаходить у властивостях звука не відомий раніше змістовний потенціал. Сучасний рівень розвитку хорового мистецтва висуває підвищені вимоги до вивчення хорової звучності, іiї основних 
елементів. Не слід позбавляти уваги питання про ставлення хорової звучності до результату виконавського враження і, відповідно, до теми, образу, стилю, драматургії тощо. Сам статус хорової звукової барвистості виступає як специфічний музичний засіб, здатний самостійно виконувати змістовні функції.

Вітакерівська «фантастика» стала виконавською реальністю новітньої хорової естетики. Американський композитор і диригент Ерік Вітакер вразив глобалізовану культурну свідомість безпрецедентною ідеєю музично-комунікативної творчої співпраці хорового колективу у віртуальному інтернет-просторі, безмежно і нескінченно розширюючи обсяг виконавців i, відповідно, звучання хору, підпорядковуючи новим функціональним можливостям віртуалізованого хорового простору мову хорової музики.

Створюється новий змістовний простір хорової музики, дослівно реалізується ідея «обніміться мільйони» засобами інтернет-простору - віртуальний хор. Так, відтворюється віртуальне і реальне охоплення хоровим звучанням усього людства. Нові хронотопи хорової музики XXI століття, які зумовили висунення на перший план звукової технології сонористику й алеаторику, забезпечуючи провідні семантичні позиції звукової барвистості хорового тембру і, водночас, принципово іншої організації фактури з іiі гармонійними складниками хорової музики. Інноваційна хорова реальність організовує нові функціональні можливості віртуалізованого хорового простору, нові програмні образні властивості хорової музики.

\section{СПИСОК ЛІТЕРАТУРИ}

1. Акопян Л.О. Музыка XX века. Энциклопедический словарь. Москва : Практика, 2010. 855 с.

2. Батюк И. К проблеме исполнения Новой хоровой музыки ХХ века : автореф. дис. ... д-ра. искусств. : 17.00.02 / Моск. гос. консерватория им. П.И. Чайковского. Москва, 1999. 47 с.

3. Білявський Є.Г. Засвоєння сучасної музичної мови в хорі. Київ : Музична Україна, 1984. 40 с.

4. Бондар Є.М. Надекспресивне інтонування в контексті сучасної хорової творчості : авторефер. дис. ... канд. мистец. : 17.00.03 / ОНМА ім. А.В. Нежданової. Одеса, 2005. 16 с.

5. Губанов Я. Кластер как интонация. Музыкальное мышление: сущность, категории, аспекты исследования. Киев : Музична Україна, 1989. С. 74-82.

6. Кошкарева Н.В. Хоровая композиция в современной отечественной музыке : автореф. дис. ... канд. искусство- 
ведения : спец. «Музыкальное искусство». Москва, 2007. URL.: http://www.dissercat.com/content/

7. Лащенко А.П. Новітні тенденції сучасного хорового мистецтва України. Музичне виконавство. Книга сьома. Науковий вісник НМАУ ім. П. І. Чайковського. Київ, 2001. Вип. 18. С. 8-25.

8. Тевлин Б.Г. Хоровые пути. Статьи. Воспоминания. Материалы. [ред.-сост. В.С. Ценова]. Москва : Музыка, 2001. 381 с., нот., ил.

9. Шульгин Д.И. Словарь музыковедческих терминов и понятий. Москва, 2010. URL.: https://refdb.ru/look/2594929-pall.html.

10. Hall, Angela. Added-Tones Sonorities in the Choral Music of Eric Whitacre D.M.A. diss., University of Washington, 2012. URL: https://openscholarship.wustl.edu/cgi/viewcontent.

11. Larson, Andrew Lloyd. Textural and Harmonic Density in Selected Choral Works (1992-2003) by Eric Whitacre. D.M.A. dissertation, University of Illinois at Urbana - Champaign, 2004. URL: https://www.ideals.illinois.edu/handle/2142/85739

12. Lynch, Shane M. Music Historiography and Useful Style Histories: The Case for the Evolving Era of Neo-Impressionism and its Influence on American Choral Music of the Late Twentieth and Early Twenty-First Centuries. D.M.A. diss., University of Washington, 2008. URL.: http://www.inform.kz/rus/article/2452616 http://ericwhitacre.com/

13. Phillip A. Swan. In His Own Words: The Choral music of EricWhitacre from 1991-2004. D.M.A. dissertation, University of Miami, 2016. URL: https://scholarship.miami.edu/discovery/delivery

14. Eric Whitacre. URL: http://www.facebook.com/pages/ EricWhitacre/

\section{REFERENCES}

1. Akopyan, L. O. (2010) Music of the XX century. Encyclopedic Dictionary. Moscow: Practice [in Russian].

2. Batyuk, I. (1999) To the problem of the performance of New choral music of the XX century. Extended abstract of candidate's thesis. Moscow [in Russian].

3. Bilyavsky, E. (1984) Assimilation of modern musical language in the choir. K.: «Musical Ukraine» [in Ukrainian].

4. Bondar, E. (2005) Overexpressive intoning in the context of modern choral creativity. Extended abstract of candidate's thesis. Odessa [in Ukrainian].

5. Gubanov, Y. (1989) Cluster as intonation. Musical thinking: essence, categories, aspects of research. Kiev: «Musical Ukraine», P. 74-82. [in Russian].

6. Koshkareva, N. (2007) Choral composition in modern native music. Extended abstract of candidate's thesis. Moscow [in Russian].

7. Lashchenko, A. (2001) New tendencies of the modern choral music of Ukraine. Musical performance. Seventh book. Kiev. Vyp. 18. P. 8-25. [in Ukrainian]. 
8. Tevlin, B. (2001) Choral paths. Articles. Memories. Materialsю. M.: Music [in Russian].

9. Shulgin, D. (2010) Dictionary of musicological terms and concepts. Moskow [in Russian].

10. Hall, Angela. (2012) Added-Tones Sonorities in the Choral Music of Eric Whitacre D.M.A. diss., University of Washington [in English].

11. Larson, Andrew Lloyd (2004) «Textural and Harmonic Density in Selected Choral Works (1992-2003) by Eric Whitacre» D.M.A. dissertation, University of Illinois at Urbana - Champaign [in English].

12. Lynch, Shane M. (2008) Music Historiography and Useful Style Histories: The Case for the Evolving Era of Neo-Impressionism and its Influence on American Choral Music of the Late Twentieth and Early Twenty-First Centuries. D.M.A. diss., University of Washington. [in English].

13. Phillip A. Swan. (2016) In His Own Words: The Choral music of EricWhitacre from 1991-2004. D.M.A. dissertation, University of Miami. [in English].

14. Eric Whitacre. URL: http://www.facebook.com/pages/ EricWhitacre/. 